\title{
Mucoid Mutants of the Biocontrol Strain Pseudomonas fluorescens CHA0 Show Increased Ability in Biofilm Formation on Mycorrhizal and Nonmycorrhizal Carrot Roots
}

\author{
Valeria Bianciotto, ${ }^{1}$ Silvia Andreotti, ${ }^{2}$ Raffaella Balestrini, ${ }^{1}$ Paola Bonfante, ${ }^{1,2}$ and Silvia Perotto \\ ${ }^{1}$ Centro di Studio sulla Micologia del Terreno-C.N.R.;'2Dipartimento di Biologia Vegetale dell'Università, V.le \\ Mattioli 25, 10125 Torino, Italy \\ Accepted 25 October 2000.
}

\begin{abstract}
Extracellular polysaccharides play an important role in the formation of bacterial biofilms. We tested the biofilmforming ability of two mutant strains with increased production of acidic extracellular polysaccharides compared with the wild-type biocontrol strain Pseudomonas fluorescens CHA0. The anchoring of bacteria to axenic nonmycorrhizal and mycorrhizal roots as well as on extraradical mycelium of the arbuscular mycorrhizal fungus Glomus intraradices was investigated. The nonmucoid wild-type strain $P$. fluorescens CHAO adhered very little on all surfaces, whereas both mucoid strains formed a dense and patchy bacterial layer on the roots and fungal structures. Increased adhesive properties of plant-growth-promoting bacteria may lead to more stable interactions in mixed inocula and the rhizosphere.
\end{abstract}

Additional keywords: alginate, PGPRs, pseudomonads, surface polysaccharides.

Plant-growth-promoting rhizobacteria (PGPRs) are associated with the plant root surface and increases plant yield by mechanisms that comprise improved mineral nutrition, disease suppression, and phytohormone production (Broek and Vanderleyden 1995; Défago and Keel 1995; Kloepper et al. 1991; Lugtenberg et al. 1991; Weller 1988). An important trait for the competitiveness of PGPRs is their ability to effectively colonize the rhizosphere and maintain a stable relationship with the plant root surface (Lugtenberg and Dekkers 1999). It was demonstrated that poor root colonization can decrease biocontrol activity (Schippers et al. 1987), and the number of take-all lesions in wheat is inversely correlated to the number of root-associated biocontrol pseudomonads (Bull et al. 1991).

PGPRs in the soil interact with the plants and a variety of soil microorganisms. Among the beneficial microorganisms, arbuscular mycorrhizal (AM) fungi are certainly the most widespread root-associated fungi in crop soil (Bethlenfalvay

Corresponding author: S. Perotto, Telephone +39 011 6502927; Fax: +39011 6707459; E-mail: perotto@ bioveg.unito.it and Linderman 1992), and current interest is focused on their antagonistic and synergistic interactions with PGPRs (Barea 1997). AM fungi increase colonization of sugar cane by PGPRs when present in mixed inocula (Boddey et al. 1991), it has been suggested that this synergism relies on physical contacts between PGPRs and AM fungi, which has been demonstrated for several wild-type and genetically modified bacterial strains (Bianciotto et al. 1996). A deeper understanding of the cellular bases of physical interactions between PGPRs, AM fungi, and plant roots, however, is an important prerequisite for the development of effective mixed inocula.

Populations of microorganisms attached to solid surfaces that comprise either single or multiple species are commonly referred to as biofilms (Costerton et al. 1995). For bacteria in natural environments, this association seems to be predominant over planktonic forms. The process of bacterial attachment to different types of abiotic and biotic surfaces has shown surprising similarities. Appendages such as pili, fimbriae, and flagella are involved in the initial attachment of bacteria to solid surfaces. Their role has been demonstrated for a number of pathogenic and beneficial plant-microbe interactions (Vande Broek and Vanderleyden 1995) and in the initiation of biofilms on abiotic surfaces by Escherichia coli and Pseudomonas spp. (O'Toole and Kolter 1998; Pratt and Kolter 1998). A firm anchoring of bacteria to the plant surface is then achieved with the production of various extracellular carbohydrate polymers (Vande Broek and Vanderleyden 1995). In addition to a role in adhesion, extracellular polysaccharides (EPS) form the matrix that embeds bacterial colonies in biofilms (Costerton et al. 1995).

Pseudomonas fluorescens strain CHA0 is a well-studied biocontrol agent of soilborne plant diseases (Voisard et al. 1994) and is naturally nonmucoid (Schnider et al. 1997). Previous investigations on the ability of PGPRs to adhere to the surface of the AM fungus Gigaspora margarita showed that strain CHA0 adheres poorly to hyphae, spores, and auxiliary cells (Bianciotto et al. 1996). Two highly mucoid strains, CHA211 and CHA213M (previously named CHA213), were derived from $P$. fluorescens strain CHA0 by the inactivation of the mucA gene (Schnider et al. 1997). Control of EPS produc- 
tion by the mucA gene, a negative regulator of alginate production, is well studied in Pseudomonas aeruginosa (Govan and Deretic 1996; Schurr et al. 1994). In mисA mutants, the mutational loss of inhibition of a sigma factor encoded by the $\operatorname{alg} U$ gene leads to activation of alginate biosynthesis and to a consequent switch to mucoidity of nonmucoid strains. In $P$. fluorescens, the complementation with a functional mucA gene could revert the mucoid phenotype of CHA211 to a wild type (Schnider et al. 1997).

The wild-type and mucoid $P$. fluorescens strains were tested for their ability to form bacterial layers on control and mycorrhizal roots with the axenic carrot root system developed by Bécard and Fortin (1988). For the assay, nonmycorrhizaltransformed carrot roots and roots colonized with Glomus intraradices were subcultured in liquid minimal $\mathrm{M}$ medium (Bécard and Fortin 1988). All bacterial strains were grown on solid King's B medium. Colonies were picked with a loop and resuspended in $50 \mathrm{mM}$ phosphate buffer, $\mathrm{pH} 7.2$, by vortexing. The concentration of bacterial cells was adjusted to $10^{7}$ to $10^{8}$ CFU per $\mathrm{ml}$, in accordance with the protocol used by Michielis et al. (1991). Fungal and root samples were transferred to a petri plate, submerged in the bacterial cell suspension, and maintained for $16 \mathrm{~h}$ at room temperature with gentle rocking. After washing with five changes of fresh phosphate buffer over $30 \mathrm{~min}$ on an orbital shaker, samples were incu- bated with the Molecular Probes Live-Dead BacLight Bacteria Viability Kit (Eugene, OR, U.S.A.) at room temperature in the dark for $15 \mathrm{~min}$, according to the manufacturer's instructions. This kit contains a proprietary mixture of nucleic acid stains that distinguish between live and dead bacteria, fluorescing green under blue light $(488 \mathrm{~nm})$ and red under green light $(514 \mathrm{~nm})$, respectively. No fixing or washing steps were used. The samples were mounted with Citifluor antifading (Agar Scientific Ltd., Stansted, U.K.) and observed under a Nikon Optiphot-2 microscope (Tokyo, Japan) with a Biorad View Scan DVC-250 Confocal system (Hemel, Hempstead, U.K.).

Similar results were obtained for mycorrhizal and nonmycorrhizal carrot roots. The pattern of distribution of wild-type and mucoid $P$. fluorescens strains in the regions where emerging or fully developed root hairs were present is illustrated at low magnification in Figure 1. After thorough rinsing of the root, only sparse green fluorescent spots corresponding to individual cells of wild-type CHA0 were visible on the root surface (Fig. 1A and B), whereas a higher number of bacterial cells as well as bacterial patches were found for CHA211 (Fig. 1C and D) and CHA213M mucoid mutants (not shown).

Bacteria were better visualized at higher magnification (Fig. 2). Individual bacteria were observed attached to the root hairs and root surface for the wild-type and mucoid strains. Mutant
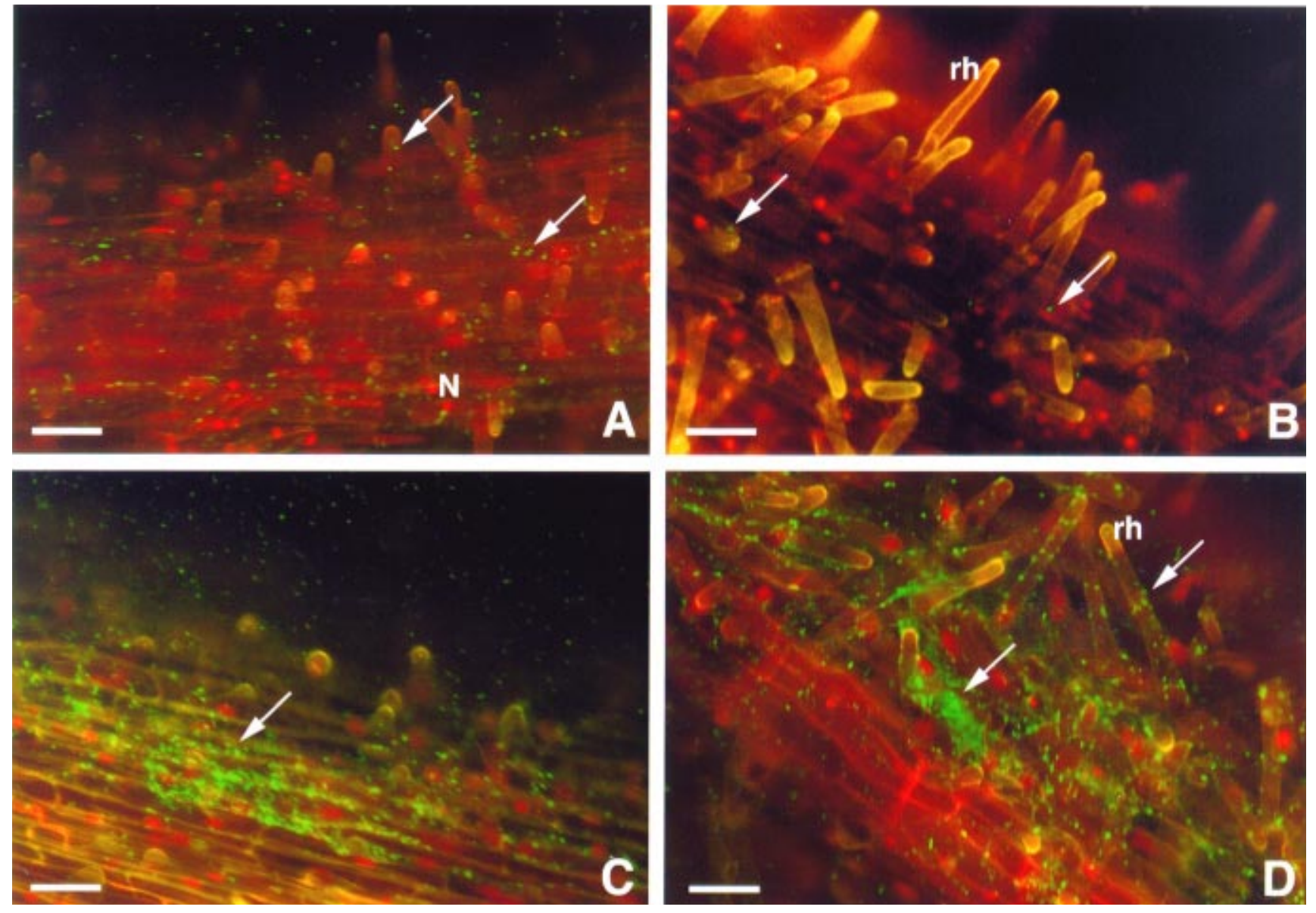

Fig. 1. Confocal microscopy image of carrot roots in the region of $\mathbf{A}$ and $\mathbf{C}$, emerging and $\mathbf{B}$ and $\mathbf{D}$, fully developed root hairs. Bacteria are visible as small green spots on the root surface. Plant nuclei are stained in red. Differences in the abundance of bacterial cells were observed when the wild-type CHA0 (A and B) or the mucoid mutant CHA211 (C and D) were used in the assay. $\mathrm{N}=$ nucleus; $\mathrm{rh}=$ root hair. Bars $=30 \mu \mathrm{m}$. 
strains often were observed in large clusters that included strands of extracellular material (Fig. 2C). Quantitative evaluation of bacterial attachment of the three strains confirmed these morphological observations (Table 1). To obtain a more detailed view of the bacterial attachment site to the surface of mycorrhizal roots, samples were prepared for transmission electron microscopy (TEM) observations after chemical fixation and embedding in LR White resin (Sigma, St. Louis, MO, U.S.A.), according to Moore et al. (1991). Only a few patches of mutant bacteria were still found on the root surface, indicating that biofilm material was lost during TEM preparation. Figure 3 shows details of the rootsbacterial interface formed with the mucoid and nonmucoid strains. The CHA211 and CHA213M cells were found either in direct contact with the epidermal cell wall or indirectly associated with the root surface as bacterial aggregates (Fig. $3 \mathrm{~A}$ and $\mathrm{B})$. An electron-dense material was visible among the bacterial cells (Fig. 3A and B) and between the bacteria and the plant cell wall (Fig. 3C). Such electron-dense material appeared as fibrils and as an amorphous matrix, suggesting structural heterogeneity. No such material was observed around cells of the nonmucoid strain CHA0 (Fig. 3E), and very few of these cells could be found on the plant surface.
Bacterial adhesion to the external mycelium of $G$. intraradices also was investigated. The results obtained with the wild-type and mucoid mutant strains mirrored those obtained already on mycorrhizal and nonmycorrhizal roots (Fig. 4). Very few bacterial cells of strain CHA0 were found on the extraradical fungal hyphae (Fig. 4A), whereas clusters of the mucoid bacterial mutants were observed on the fungal surface (Fig. 4B and C). A quantitative evaluation of bacteria is presented in Table 1. Similar results also were obtained when inorganic glass fibers were used as a solid substrate in the same assay (data not shown).

Table 1. Quantitative evaluation of bacteria on root and fungal surfaces ${ }^{\mathrm{a}}$

\begin{tabular}{lcc}
\hline Bacterial strains & Roots surface & Fungal surface \\
\hline CHA0 & $5.0 \pm 1.56 \mathrm{a}$ & $1.8 \pm 1.31 \mathrm{a}$ \\
CHA211 & $70.6 \pm 6.14 \mathrm{~b}$ & $56.0 \pm 5.69 \mathrm{~b}$ \\
CHA213M & $69.9 \pm 11.49 \mathrm{~b}$ & $54.25 \pm 5.50 \mathrm{~b}$ \\
\hline
\end{tabular}

a Prints from confocal micrographs at the same magnification were used. The number of bacteria present over a chosen area was determined in ten photos for each bacterial strain. The mean number \pm standard deviation of bacteria per $3 \mathrm{~cm}^{2}$ area is reported. Values not sharing the same letter are significantly different according to the Mann-Whitney test $(P<0.001)$
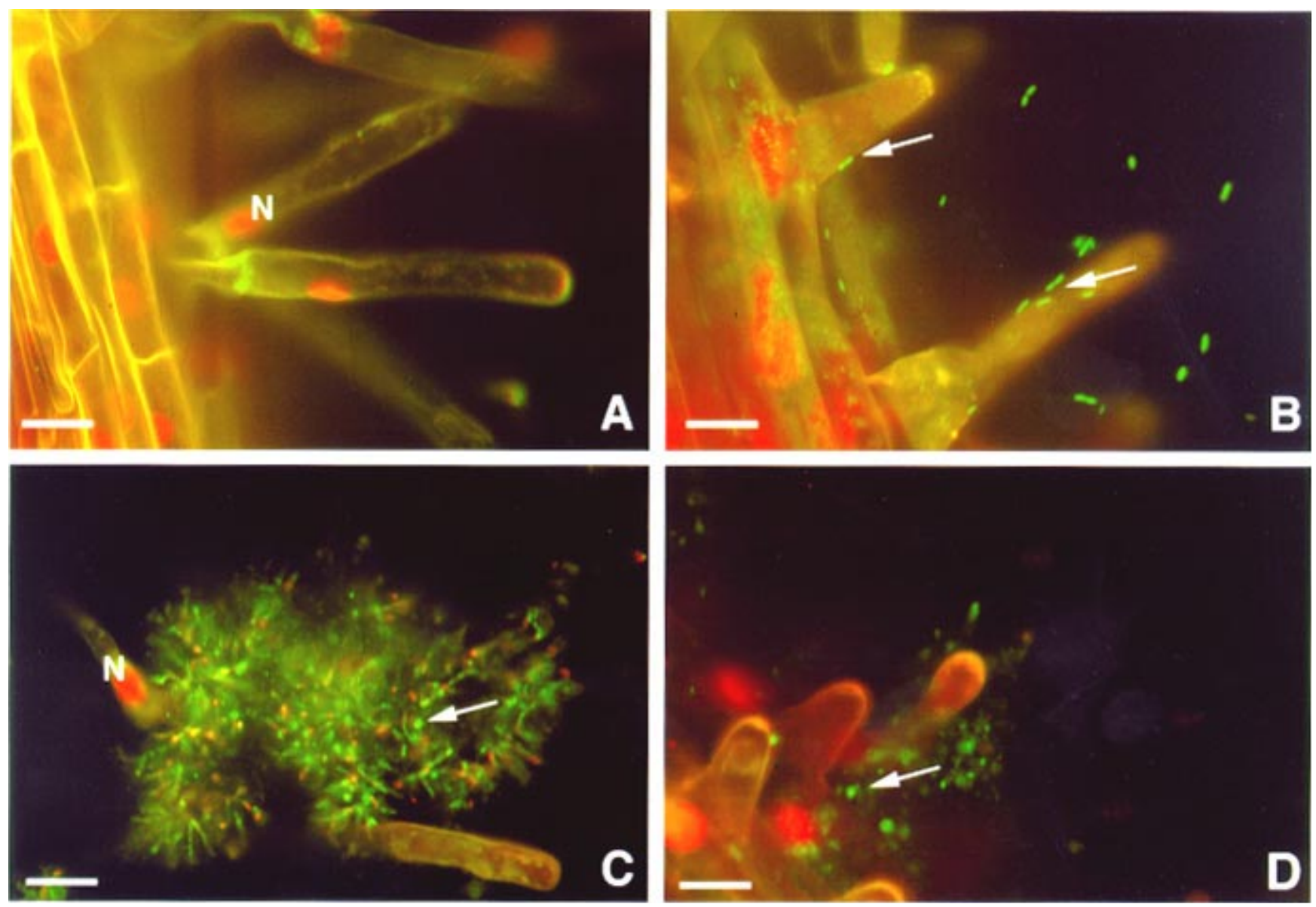

Fig. 2. Higher magnification of the carrot root surface as viewed by confocal microscopy. Plant nuclei $(\mathrm{N})$ are stained in red and are visible in the epidermal cells and within root hairs. A, Control root where no bacteria were used in the assay. B, Attachment of wild-type strain CHA0 to the root surface. Bacteria are visible as small green spots and, in many cases, appear to be involved in division (arrows). C, Bacterial cluster formed by strain CHA211. Bacterial cells are embedded in matrix material and are visible in some points as rows of cells. Dead bacteria (stained in red) are trapped in the matrix. D, Tip of root hairs is in focus and shows the presence of bacteria (strain CHA213M) embedded in a matrix (arrow). Bars $=10 \mu \mathrm{m}$. 
Our results demonstrate that the alginate-like EPS of $P$. fluorescens is involved in vitro in the association of bacteria with solid substrates such as roots and AM surfaces because EPS overproducing mutants are able to form a more conspicuous bacterial layer compared with the nonmucoid wild type. Ultrastructural studies suggest that this polymeric extracellular material is likely involved in bacterial aggregation and attachment to these biotic surfaces. The role of alginates in bacterial adhesion and biofilm formation has been studied in detail for $P$. aeruginosa. It was shown that alginate improves attachment and anchoring of strains of $P$. aeruginosa to several surfaces and is the main constituent of the biofilm matrix material (Boyd and Chakrabarty 1995). Non-EPS producing strains can attach to solid abiotic surfaces but are unable to form biofilms (Allison and Sutherland 1987), as also demonstrated in microplate adhesion assays for Deleya (Pseudomonas spp.) marina (Schea et al. 1991).

Root colonization and competition, especially in natural environments, relies on a number of features such as rate of cell division and motility (Lugtenberg and Dekkers 1999). Additional experiments are needed to establish whether increased mucoidity influences the ability of bacteria to colonize the surface of AM fungi and roots, either directly or by interfering with other characters.

Increased EPS production in the mucoid derivatives of $P$. fluorescens CHA0 may have a biotechnological interest. A general role of EPS is the protection of bacterial cells against desiccation and harsh environments (Ophir and Gutnick

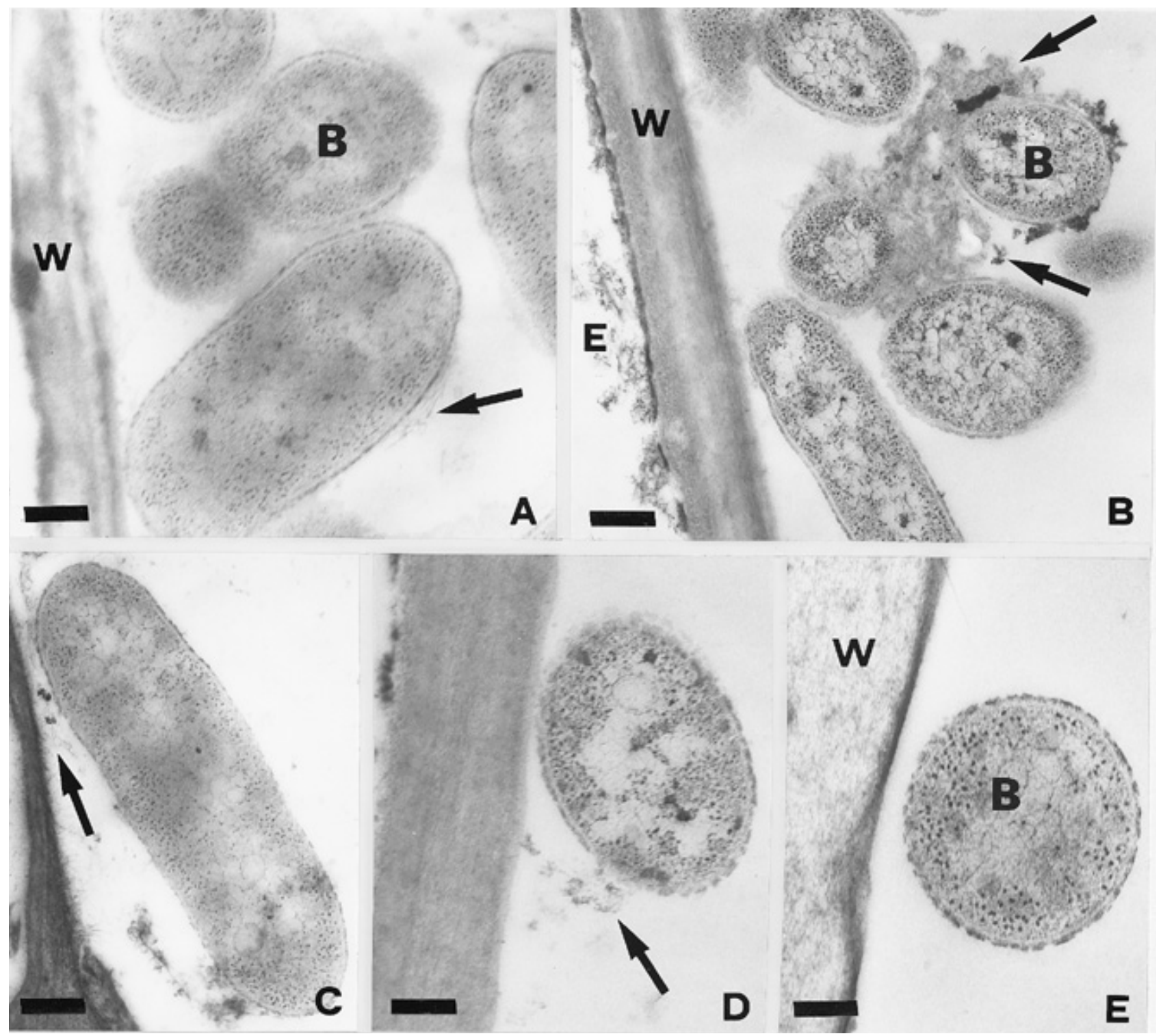

Fig. 3. Electron micrographs of the bacterial attachment site to the plant cell wall. A, Cluster of the mucoid bacterial strain CHA211 adheres to the plant wall. Within the cluster, a clump of electron-dense material can be seen (arrows). B, Similar pattern is observed with the mucoid bacteria strain CHA213M. C to E, Adhesion site of single bacterial cells to the epidermal cell wall. C and D, CHA211 and CHA213M, respectively. Extracellular material is visible between the bacteria and the root surface (arrows). The nonmucoid strain CHA0 shows very little ability to associate with the root surface and no extracellular electron-dense material is found around the bacterial cell or near the plant surface. $\mathrm{W}=$ plant cell wall; $\mathrm{E}=$ epidermal cell; $\mathrm{B}=$ bacteria. Bars $=\mathbf{A}$ to $\mathbf{C}, 0.3 \mu \mathrm{m} ; \mathbf{D}$ and $\mathbf{E}, 0.2 \mu \mathrm{m}$. 

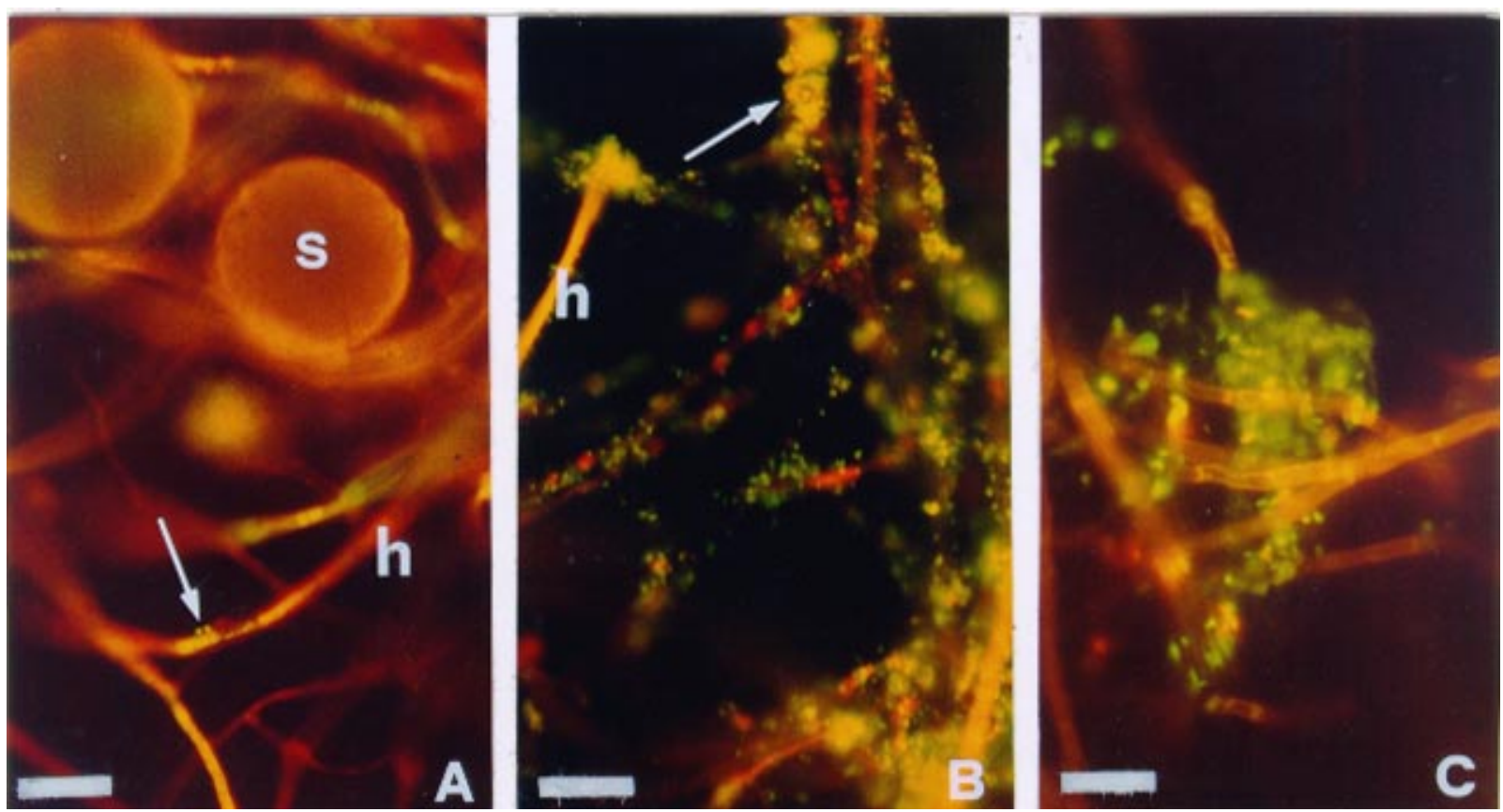

Fig. 4. Association of wild-type and mucoid strains to external mycelium of Glomus intraradices. A, Nonmucoid strain CHA0 shows very little ability to associate with the external mycelium and spores of $G$. intraradices. Bacterial cells rarely were found (arrow) on the fungal structures. B, Mucoid strain CHA211 forming a dense bacterial layer on the external hyphae (arrow). C, Higher magnification of external fungal hyphae to show the presence of CHA213M bacteria, which is seen embedded in a matrix. $\mathrm{S}=$ spore; $\mathrm{h}=$ hypha. Bars $=\mathbf{A}$ and $\mathbf{B}, 30 \mu \mathrm{m} ; \mathbf{C}, 10 \mu \mathrm{m}$.

1994), and it should therefore be elucidated whether survival of strains CHA211 and CHA213M in the soil may benefit from their increased mucoidity.

The wild-type strain CHA0 displays biocontrol activity and performance of the derived mucoid strains in root colonization and against fungal pathogens in gnotobiotic systems is currently under investigation (U. Schnider and C. Keel, personal communication). Data obtained in petri plates suggest that the antifungal compounds responsible for biocontrol activity remain entrapped in the EPS of mucoid strains where they reach a high local concentration (Schnider et al. 1997). It is important to elucidate whether this feature of mucoid colonies leads to increased plant protection, with the thicker bacterial biofilm forming a shield rich in bioactive compounds around the root, or whether a limited diffusion of these compounds hampers biocontrol activity.

In conclusion, cellular analysis of the interactions occurring among plants, AM fungi, and wild-type and mutant bacteria may provide relevant information for the development of the "second-generation inocula" on the basis of selected mixtures of PGPR and AM fungi (Calvet et al. 2000). Irrespective of the specific functional abilities of the selected bacteria, the presence of EPS seems to be an essential trait for a stable fungus-bacteria association.

\section{ACKNOWLEDGMENTS}

We thank D. Haas, U. Schnider, and C. Keel for providing bacterial mutants and for helpful discussions. We are thankful to A. Fortin (University of Montreal, Canada) for the transformed root system and A. Genre for technical assistance with the fluorescence images. Research was funded by the EU IMPACT2 project (BIO-CT96-0027) and by C.N.R.

\section{LITERATURE CITED}

Allison, D. G., and Sutherland, I. W. 1987. The role of exopolysaccharides in adhesion of freshwater bacteria. J. Gen. Microbiol. 133:13191327.

Barea, J. M. 1997. Mycorrhiza/bacteria interactions on plant growth promotion. Pages 150-158 in: Plant Growth-Promoting Rhizobacteria: Present Status and Future Prospects. A. Ogoshi, K. Kobayashi, Y. Homma, F. Kodama, N. Kondo, and S. Akino, eds. OECD Paris.

Bécard, G., and Fortin, J. A. 1988. Early events of vesicular-arbuscular mycorrhiza formation on Ri T-DNA transformed roots. New Phytol. 108:211-218

Bethlenfalvay, G. J., and Lindermann, R. G., eds. 1992. Mycorrhizae in Sustainable Agriculture. ASA Special Publication No. 54. Madison, WI, U.S.A.

Bianciotto, V., Minerdi, D., Perotto, S., and Bonfante, P. 1996. Cellular interactions between arbuscular mycorrhizal fungi and rhizosphere bacteria. Protoplasma 193:123-131.

Boddey, R. M., Urquiaga, S., Reis, V., and Doberreiner, J. 1991. Biological nitrogen fixation associated with sugar cane. Plant Soil 137:111-117.

Boyd, A., and Chakrabarty, A. M. 1995. Pseudomonas aeruginosa biofilms: Role of the alginate exopolysaccharide. J. Ind. Microbiol. 15:162-168.

Broek, A. V., and Vanderleyden, J. 1995. Genetics of the Azospirillumplant root association. Crit. Rev. Plant Sci. 14: 445-466.

Bull, C. T., Weller, D. M,. and Thomashow, L. S. 1991. Relationship between root colonization and suppression of Gaeumannomyces graminis var. tritici by Pseudomonas fluorescens strain 2-79. Phytopathology 81:954-959.

Calvet, C., Camprubi, A., Estaun, V., Sabadell, S., Aguado, A., Ferrer, I., Jaizme-Vega, M. C., Cid, M. C., Hernandez, J., Tenoury, P., Rodriguez, A. S. 2000. Integration of arbuscular mycorrhizas and other beneficial soil microbiota in horticultivar cropping systems. Pages 18-20 in: Cost Action 838 Meeting, Managing Arbuscular Mycorrhizal Fungi for Improving Soil Quality and Plant Health in Agriculture. Santiago de Compostela, Galicia, Spain.

Costerton, J. W., Lewandowski, Z., Caldwell, D. E., Korber, D. R., and Lappin-Scott, H. M. 1995. Microbial biofilms. Annu. Rev. Microbiol. 49:711-45. 
Défago, G., and Keel, C. 1995. Pseudomonads as biocontrol agents of diseases caused by soilborne pathogens. Pages 137-148 in: Benefits and Risks of Introducing Biocontrol Agents. H. M. T. Hokkanen and J. M. Lynch, eds. University Press, Cambridge, U.K.

Govan, J. R., and Deretic, V. 1996. Microbial pathogenesis in cystic fibrosis: Mucoid Pseudomonas aeruginosa and Burkholderia cepacia. Microbiol. Rev. 60:539-574.

Kloepper, J. W., Zablotowick, R. M., Tipping, E. M., and Lifshitz, R. 1991. Plant growth promotion mediated by bacterial rhizosphere colonizers. Pages. 315-326 in: The Rhizosphere and Plant Growth. D. L. Keister and P. B. Cregan, eds. Kluwer Academic Press, Dordrecht, The Netherlands.

Lugtenberg, B. J. J., and Dekkers, L. C. 1999. What makes Pseudomonas bacteria rhizosphere competent? Environ. Microbiol. 1:9-13.

Lugtenberg, B. J. J., De Weger, L. A., and Bennett, J. W. 1991. Microbial stimulation of plant growth and protection from disease. Curr. Opin. Microbiol. 2:457-464.

Michielis, K. W., Croes, C. L., and Vanderleyden, J. 1991. Two different modes of attachment of Azospirillum brasilense $\mathrm{Sp} 7$ to wheat roots. J. Gen. Microbiol. 137:2241-2246.

Moore, P. J., Swords, M. M., Lynch, M. A., Staehelin, L. A. 1991. Spatial organization of the assembly pathways of glycoproteins and complex polysaccharides in the Golgi apparatus of plants. J. Cell Biol. 112:589-602.

Ophir, T., and Gutnick, D. L. 1994. A role of exopolysaccharides in the protection of microorganisms from desiccation. Appl. Environ. Microbiol. 60:740-745.

O'Toole, G. A., and Kolter, R. 1998. Flagellar and twitching motility are necessary for Pseudomonas aeruginosa biofilm development. Mol. Microbiol. 30:295-304.

Pratt, L. A., and Kolter, R. 1998. Genetic analysis of Escherichia coli biofilm formation: Roles of flagella, motility, chemotaxis and type I pili. Mol. Microbiol. 30: 285-293

Schea, C., Nunley, J. W., Williamson, J. C., and Smith-Somerville, H. E. 1991. Comparison of the adhesion properties of Deleya marina and the exopolysaccharide-defective mutant strain DMR. Appl. Environ. Microbiol. 57:3107-3113.

Schippers, B., Bakker, A. W., and Bakker, P. A. H. M. 1987. Interactions of deleterious and beneficial rhizosphere microorganisms and the effect of cropping practices. Annu Rev. Phytopathol. 25:339-358.

Schnider, U., Keel, C., Blumer, C., Michaux, P., Défago, G., and Haas, D. 1997. Regulation of mucoidity in the biological control agent Pseudomonas fluorescens CHA0 and construction of an exopolysaccharide-overproducing variant. Pages 349-352 in: Plant GrowthPromoting Rhizobacteria: Present Status and Future prospects. A. Ogoshi, K. Kobayashi, Y. Homma, F. Kodama, N. Kondo, and S. Akino, eds. OECD, Paris.

Schurr, M. I., Martin, D. W., Mudd, M. H., and Deretic, V. 1994. Gene cluster controlling conversion to alginate-overproducing phenotype in Pseudomonas aeruginosa: Functional analysis in a heterologous host and role in the instability of mucoidity. J. Bacteriol. 176:3375-3382.

Vande Broek, A., and Vanderleyden, J. 1995. The role of bacterial motility, chemotaxis and attachment in bacteria-plant interactions. Mol. Plant-Microbe Interact. 8:800-810.

Voisard, C., Bull, C. T., Keel, C., Laville, J., Maurhofer, M., Schnider, U., Défago, G., and Haas, D. 1994. Biocontrol of root diseases by Pseudomonas fluorescens CHA0: Current concepts and experimental approaches. Pages 69-89 in: Molecular Ecology of Rhizosphere Microorganisms. F. O'Gara, D. N. Dowling, and B. Boesten, eds. VCH, Weinheim, Germany.

Weller, D. M. 1988. Biological control of soilborne plant pathogens in the rhizosphere with bacteria. Annu. Rev. Phytopathol. 26:379-407. 